Fecha de recepción: I septiembre 2org

Fecha de aceptación: 2 noviembre 2019

Fecha de publicación: 9 febrero 2020

URL: https://oceanide.es/index.php/or2020/article/view/49/192

Oceánide número I3, ISSN 1989-6328

DOl: https://doi.org/I0.37668/oceanide.vizi.49

\title{
Literary Contributions
}

\section{$\approx$ Paddy Bushe}

Paddy Bushe was born in Dublin in 1948 and now lives in Waterville, Co. Kerry. He writes in Irish and in English. His collections include Poems With Amergin (1989), Digging Towards The Light (1994), In Ainneoin na gCloch (2001), Hopkins on Skellig Michael (2001) and The Nitpicking of Cranes (2004). To Ring in Silence: New and Selected Poems was published in 2008. He edited the anthology Voices at the World's Edge: Irish Poets on Skellig Michael (Dedalus, 2010). His latest collections are My Lord Buddha of Carraig Eanna (2012), On A Turning Wing (2016) and Móinéar an Chroí (2017). He received the 2006 Oireachtas prize for poetry, the 2006 Michael Hartnett Poetry Award and the 2017 Irish Times Poetry Now Award. He is a member of Aosdána. In 2020, Dedalus Press publishes Double Vision, a two-volume publication comprising Second Sight, the author's own selection of his Irish language poems, accompanied by the author's own translations, as well as Peripheral Vision, his latest collection in English.

\section{$\approx$ Bernard O'Donoghue}

Bernard O'Donoghue's was born in Cullen, County Cork in 1945, he has lived in Oxford since 1965. His first full-length collection, The Weakness, emerged in I99I with Chatto \& Windus, following on from a trilogy of pamphlets. His second collection, Gunpowder (i995) won the Whitbread Poetry Award. More recently, he published the collection Outliving and a selection of his poetry by Faber in 20o8, followed by Farmers Cross (2011), which was shortlisted for the T.S. Eliot Prize. In 2009 he was honoured by the Society of Authors with a Cholmondeley Award. Until recently, O'Donoghue taught and worked for Oxford University, specialising in medieval verse and contemporary Irish literature. His reputation as a scholar consolidated in 1995 with his critical work, Seamus Heaney and the Language of Poetry, described as "excellent" by Ian Sansom in The Guardian. More recently O'Donoghue edited the Cambridge Companion to Seamus Heaney and has produced a number of translations of medieval works, including Gawain and the Green Knight (2006) and, forthcoming from Faber, Piers Plowman.

\section{Suso de Toro}

Xesús Miguel "Suso" de Toro Santos (1956-) is a Spanish writer. A modern and contemporary arts graduate, he has published more than twenty novels and plays in Galician. He is a television scriptwriter and regular contributor to the press and radio. Suso de Toro writes in Galician and sometimes translates his own work into Spanish.

His works have been translated into several languages, and have been taught in European universities. There are plans to make three of his works into films: A Sombra Cazadora (1994), Non Volvas (1997), and Calzados Lola (2000). 


\section{$\sim$ Afternoon Pilgrimage}

for Antonio Raúl de Toro Santos

Because it had been said we must visit Santo André de Teixido while we live, Or else be spirited there later as toads

Or lizards, we set off down the steep path Marked by votive cairns and stitched tightly Into tumbled granite by sea-pink and crocus,

Clambering down ladders of heat and light And along a path beaten through yew trees Whose shadowing gave the village its name.

Mica and quartzite flashed here and there Among the boulders, whispering insistently About that otherworld long since denied.

The path steadily dipped and dropped Along abrupt zigzags that turned back On themselves like an endless argument,

Down to orange tiles, stone walls and narrow Twisting lanes pungent with dung and straw, Then the village, the fountain, the church

Pied with slated stone and gleaming mortar, Overflowing with candlelight and painted Breadcrumb statues hawked in the square.

And as we left, past the parking area jammed With buses, and along the double yellow lines Of the new access road, it was hard to make out

Which way we had come down, which world We had entered or left or which way back up Would lead to wherever it was we were going. 


\section{$\frown$ Fire-Lighters}

His house was so wet and cold in winter there was no question of doing without a fire. But how did people start a fire? He placed the whole packet of Zip cubes in the grate and struck a match. Briefly the room lit up, and a friendly warmth embraced him, enough nearly to make him sing. But it didn't last: a few minutes, and it was dark and cold again. This was how it had always been: the flare of friendship or acclaim - 'Good man, O'Connor!' in the pub, followed by the long times of indifference and neglect. So he'd pull the soaking blanket over him and wait for the cold, unfeeling light at break of day.

\section{$\simeq$ The Anchorage}

One morning in the hot summer of ' 59

We watched through binoculars a black cloud Of smoke on the skyline. Someone suggested It must be furze being burned on the banks Of the railway-line. But word spread That it was Bill Casey's barn, new-packed With this year's hay. We all went to see it, And smelled the dead smell of burning. Casey kicked ruefully at the iron staple In the wall which the dog had been chained to. All the farmers in the parish rallied round; The next Sunday a long cortege of horse-floats Made their slow way along the dusty road To Ardnageeha to repair the loss.

But what good was that? The barn's dark pillars Did not lighten, and when you closed your eyes What you saw was the invisible

Last hours of the desperate, leaping dog.

Bernard O'Donoghue - two unpublished poems 


\section{Un mestre na casa}

Somos unha familia numerosa, seis irmáns varóns, e neses casos os irmáns son unha referencia educadora moi forte. Como son irmán de Antonio Raúl debera dicir algo del, limitareime a un par de cousas elementais. Antonio foi un neno que tivo unha infancia moi alegre e que inmediatamente antes de chegar á adolescencia xa tivo que cargar con responsabilidades. De modo que deu esa persoa que vós coñecestes, un cruce de entusiasmos coa gravidade de quen asume responsabilidades. E unha inquedanza perpetua, ben por algún xen eléctrico ben polas circunstancias da nosa vida, os De Toro somos incapaces de estármonos quedos.

Como todo irmán maior foi alguén tocoulle abrir camiños para os demais irmáns. Para min Antonio foi, sen el sabelo, un mestre na casa. Desde moi neno lémbrome con ansias, preocupacións e soños e non tería sido quen a darlle forma a esas ilusións e soños se non fose porque Tonio achegou a casa tantas cousas que el mesmo non lembra.

Desde logo con el entrou en casa a cultura en lingua inglesa que entón, logo dos acordos entre os USA e o Réxime de Franco que permitiron aos americanos establecer as bases militares e afondar no proceso de colonización cultural, comezaba a ocupar a referencia lingüística e cultural que outrora foran Alemaña ou Francia. No comezo dos anos 6o foi o tempo no que ás radios emitían música andaluza española e canción italiana, mais na nosa casa como noutras tantas entrou o pick up, o "picú", e con el os discos dos Tamara e tamén os dos Beatles. A música en lingua inglesa entrou para ficar e xa foi o ámbito no que nos instalamos en adiante, Antonio estudou inglés, fíxose anglófilo e tras del fomos os demais.

Ademais da historia familiar a cada quen educounos a comunidade, no noso caso unha cidade moi concreta, Santiago, que tiña dentro un mundo propio, a universidade. A cidade, e a circunstancia de traballar desde rapaz no negocio familiar, fixo de Antonio alguén que coñece a diversidade social e a universidade fixo del un espírito crítico.

$\mathrm{O}$ da guitarra, que recuperou nos últimos tempos, e a música ven xa da adolescencia, cando comprou a primeira cos seus aforros pois a casa daqueles adolescentes foi unha casa musical, en torno do "picú" reuníanse compañeiros de estudos que traían os seus discos para escoitar alí en grupo. Sen orde nin concerto, a música foi parte do ambiente no que se formou e a alegría, o sentido societario e o gusto pola música levouno ao coro de música tradicional de Santiago, "Cantigas e Agarimos". Alí, ademais de cantar, actuou nunha representación de "Os vellos non deben namorarse" do Castelao naqueles anos. Lembro a Tonio coa súa guitarra entoando "Lela", a peza que se fixo popular nestes últimos anos.

O 68 foi unha pequena revolución que encheu de alegría e de ideas novas a cidade. Foi a celebración da disidencia e da posibilidade de probar a vivir en liberdade, foi a recuperación do galeguismo e a chegada das ideas democráticas que estaban agochadas e que se estenderon polas rúas da cidade. E cada un, cada unha daqueles mozos e mozas levaban de volta aquela mensaxe nova ás súas casas nas cidades e vilas do noso país. Así chegaron a casa os poemas de Celso Emilio Ferreiro e as letras de cancións de Pete Seeger en papel ciclostil de man en man, e os discos de Voces Ceibes, cando a nosa lingua se transformou na bandeira dunha nova xeración. E tamén a revista "Chan" en galego e castelán, editada por aquel vello socialista, Borobó, que xa dirixira anos antes o suplemento de letras de "La Noche", onde comezou o renacemento das nosas letras na posguerra.

E na casa, pola man de Antonio, xunto cos libros das carreiras respectivas foron aparecendo libros de arte e de Freud, Marcuse, Erich Fromm, Marx, Gramsci...E o Lenin en inglés, "What to do?", traído secretamente de Londres. E "La marginación de Galicia" de Paz Andrade, editada en México, tamén por Siglo XXI.

E Joyce, claro. A través da guía de Stuart Gilbert que editou en castelán Siglo XXI. A manía de Joyce xa ven de vello, a cousa non ficou en anglofilia senón que continuou na simpatía por Irlanda.

Tonio, sen el saber, abriu unha escola na nosa casa e desa escola tan aberta e feita de curiosidade aprendemos os que viñamos detrás. Non vexo no que son intelectualmente eu agora nada que non estivera xa naquela escola.

\section{Suso de Toro}

\section{A Teacher at Home}

We are a large family of six brothers and, in such situations, brothers are a strong educational influence. As I am a brother of Antonio Raúl, I should say something about him and shall limit this to a few key points. Antonio was a boy who enjoyed a very happy childhood. Just before he reached adolescence, he had to take on responsibilities. That was what shaped the person you know today: a combination of enthusiasm and the gravitas of someone who assumes responsibilities. A perpetual restlessness: perhaps because of some electric gene or perhaps because of the circumstances of our lives, we De Toros are incapable of staying still. 
Like all older brothers, he had to forge a way ahead for the other brothers too. For me, Antonio was, without being aware of it, like a teacher at home. When I was a very young child, I had worries, concerns and dreams and would not have been able to give shape to those hopes and dreams if Tonio had not brought home more things than even he can recall.

Firstly, English-language culture entered our home through him. Because of the agreements between the USA and the Franco regime, which allowed the Americans to establish military bases and further the process of cultural colonization, the linguistic and cultural reference point that was English was beginning to surpass that of Germany or France. The early ig6os was the time when radios would broadcast Andalusian music and Italian songs, but in our house, like most others, there was the "pickup" and records by Tamara and the Beatles. English-language music was there to stay and from that point on was the environment in which we all found ourselves: Antonio studied English, became an Anglophile and the rest of us followed on behind.

In addition to family history, we were all influenced by our community, or in our case, one city specifically, Santiago, within which there lay another world entirely: the university. The city and the circumstance of working since he was a boy in the family business made Antonio someone who was aware of social diversity, and university gave him a critical outlook.

The guitar, to which he has recently returned, and music, comes from his teenage years, when he bought the first instrument with his savings. The house for those teenagers was a musical house: fellow students would gather around the pickup, listening together to the records they had brought along. Without rhyme or reason, music was part of the atmosphere in which we grew up, and happiness, the sense of society and enjoyment of music led us to the traditional Galicia music choir in Santiago, "Cantigas e Agarimos" [Songs and Warmth]. At that time, as well as singing there, Antonio acted in a performance of "Os vellos non deben namorarse" [Old Men Shouldn't Fall in Love], a play by Castelao. I remember Tonio with his guitar striking up "Lela", a song that has become popular in recent years.

I968 was a small revolution which filled the city with new ideas and joy. It was the celebration of dissidence and the chance to experience a life of freedom. It was the recovery of pro-Galician sentiment and the arrival of democratic ideas that had been waiting to emerge and which now spread through the streets of the city. Every one of those young men and women took that new message back to their homes in the cities and towns of Galicia. That was how the poems of Celso Emilio Ferreiro and the lyrics to Pete Seeger songs entered homes, on cyclostyle paper, passed from hand to hand, and the records of Voces Ceibes [Free Voices], when our language became the standard of a new generation. There was also "Chan" [Earth] magazine, published in Galician and Castilian and edited by that old socialist, 'Borobó', who years before had led the literary supplement "La Noche" [The Night], where the renaissance of Galician literature began in the period following the Civil War.

In our house, through Antonio and the texts from everyone's university courses, art books and works by Freud, Erich Fromm, Marx and Gramsci began to appear. Plus, Lenin in English, "What Is To Be Done?", brought secretly from London, and "La marginación de Galicia" [The Marginalization of Galicia] by Paz Andrade, published in Mexico also by Siglo XXI.

And Joyce, of course, through the Stuart Gilbert guide published in Castilian by Siglo XXI. The passion for Joyce was long held and went from Anglophilia to enthusiasm for Ireland.

Without even knowing it, Tonio opened a school in our home and we who followed on behind him learnt so much from that school, so open and founded upon curiosity. Everything I am today in intellectual terms was shaped by that school.

Suso de Toro, translated by John Barlow 